\title{
River Bed Cultivation: A Kind of Vegetable Forcing for Remunerative Returns
}

\author{
Reena Kumari $^{1 *}$, Ankita Sharma ${ }^{1}$, Shikha Bhagta ${ }^{2}$ and Ramesh Kumar ${ }^{1}$ \\ ${ }^{1}$ Department of Vegetable Science, Dr YS Parmar University of Horticulture and Forestry, \\ Nauni-173 230, Solan, HP, India \\ ${ }^{2}$ Department of Tree Improvement and Genetic Resources, Dr YS Parmar University of \\ Horticulture and Forestry, Nauni-173 230, Solan, HP, India
}

*Corresponding author

\begin{abstract}
A B S T R A C T
Presently, in South Asian countries, majority of cucurbitaceous vegetables are extensively being grown in riverbeds (called diara land) for off season produce. Growing cucurbitaceous vegetables on river-beds or river basins constitute a distinct type of farming. River bed cultivation is a kind of vegetable forcing is being used in India

Keywords

Cucurbits,

Riverbed, Diara land, Alluvion and ailuvion

\section{Article Info}

Accepted:

04 March 2018

Available Online:

10 April 2018

facilitating off season production of cucurbitaceous vegetables, where cucurbits are grown in the river beds during winter season. It is a very old practice of growing cucurbits on bank or basin of the river during the dry season or on the land that is subject to annual flooding. Seasonally dry riverbeds are an under utilized resource that can be used for sustainable vegetable production. Climate change induced floods and the encroachment of riverbeds are silting over arable land and increasing the area of sandy riverbeds. These river beds are formed and subjected to alluvion and diluvion action of perennial Himalayan Rivers and due to inundation caused by swollen rivers during South-West monsoon. Vast tracks of riverbeds are dry and fallow during the period from October to May. Besides cucurbits, other high value crop like tomatoes is also successfully cultivated due to its deep root system. It can be treated as a kind of vegetables forcing where in the cucurbits are grown under sub-normal conditions, literally on sand, during winter months from November-February, especially in North and North-Western India. Riverbed farming can be used to increase household income and to improve the food security of landless and land poor households of India.
\end{abstract}

\section{Introduction}

About $65 \%$ of total cucurbit cropped area of the country falls under riverbeds. Riverbed commonly known as Diara land is a basin or bank area or area between two or more stream of river and known as Khadar, Kachhar, Doab, Dariyari, Kochsr, Nad, Tali and
Nadiari by several local names. The term "Diara" has been derived from the word 'Diya' meaning earthen lamp. Keeping in conformity with the shape of the 'Diya', the bowl like systems on the surface (depressions) situated between the natural levees on either side of the river appear like small 'Diyas' when rain water gets 
accumulated in them during the rainy session. Diara lands are extensively found in Uttar Pradesh, Bihar, Assam and Orissa. Usually these lands are available only for a short period, and landless, small and marginal farmers cultivate on these lands the seasonal vegetables and fruits. River bed cultivation of cucurbits is practiced along the river Yamuna, Ganges, Gomti, Sarju and other distributaries in Haryana, Uttar Pradesh, and Bihar, Banas river in Tonk, Rajasthan; Narmada, Tawa and Tapti rivers in Madhya Pradesh and Maharashtra; Sabannati, Panam, Vartak and Orsung in Gujarat; Tungbhadra, Krishna, Hundri and Pennar rivers in Andhra Pradesh, and Parnba and Manimala river beds in Kerala. The soil in river beds contains mostly sand and moisture is seeped from the adjacent river.

After the monsoon season, the water from the riverbeds retreats back to its channel, leaving large areas dry. These areas of land are generally left unused due to the austerity in management, conflicts of land ownership, difficult access and lack of overall motivation to cultivate marginal land. However, these riverbed areas furnish a diversity of natural resources. Proper management of the riverbeds would contribute to income generation as well as to natural resources management (minerals, forest, biodiversity, water, ecology and changing climate) and better disaster/risk management.

Apart from these issues, riverbeds offer opportunities for the landless (sukumbashi) and land-poor people in their vicinity for income generation and food security. Landless people are defined as individuals having less than 0.13 ha land, while land-poor people are individuals having between 0.13 and 0.3 ha land. It can be concluded that from the land availability point of view, it is definitely worthwhile to explore in greater detail how riverbeds could become more relevant from a livelihood and social point of view. The cultivation practices on the riverbeds are of different nature and face a large number of problems, related to irrigation, fertilization, and seed problem etc.

\section{Importance and Scope}

Riverbed farming is horticulture cultivation on the common lands in riverbeds which are dry and accessible during the post-monsoon season, i.e. October to May.

After the river water recedes, vegetables can be planted in ditches dug into the seasonal sand banks, and the crops harvested before the onset of the next monsoon. Riverbed farming can be used to increase household income and to improve the food security of landless and economically poor people. The key reasons of the expansion of this practice is mainly due to availability of fertilizers and nutrients and improved agriculture technologies, easy availability of riverbeds, access to transportation and markets.

This system is unconnected with any other crop rotations and cucurbits are specially adapted to this system of growing due to their long tap root system.

This type of cultivation is practiced on low priced sandy soils along the beds of the rivers, on bare, active sand-dunes in sandy regions gives protection to dunes and no sand blowing takes place with their vines mulching the soil during summer months. Even though upper layers of land seem unsuitable for growing crops, the subterranean moisture seeped from adjacent river, streams, make it possible to grow early crops.

\section{Advantages of riverbed cultivation}

There are several advantages of river bed cultivation, which includes: 
High net return per unit area

Early and high yield

Ease in irrigation

Low cost of cultivation

Less mineral requirement due to high fertility

Limited weed growth

Easy in control of pest and disease by cultural means

Low cost labour facilities

No land ownership required

High economic returns of Rs $16,500 \mathrm{~kg} / \mathrm{ha}$ can get out of cucurbit vegetables cultivation

Income and food security of landless and marginal farmers

Local adaptation to climate change

\section{Where it works}

The technology works well on marginal lands, in topographically flat areas with river beds that are dry for one crop cycle (approximately 6 months). Typical successful adopters are landless and land-poor households and farmers with arable land silted over and/or washed away due by floods.

Distance/Adjoining to village: not more than 30 minutes on foot.

Sand must be fine and small-grained and the groundwater table should be $<1 \mathrm{~m}$.

Riverbeds or riverbanks may be cultivated. Riverbeds have a higher soil moisture content compared to riverbanks, obviating the need for irrigation, but bear higher risks of total crop loss due to winter or early spring floods.

\section{Classification of Diara land on the basis of distance from the main stream}

Lower diara lands: are located in the main river beds that have fine sand to courses and deposits on the surface and are available for cultivation of different crops and vegetables during non-monsoon seasons (November/ December to May/June).

Middle diara lands: are located on the banks of the rivers. The width of such lands varies considerably as the areas are frequently inundated during rainy seasons by swelling flood waters. The depth of flooding however varies considerably at different locations.

Upper diara lands: are those lands which, during the course of continuous depositions get elevated and are less frequently flooded, in comparison to the middle diara lands.

\section{Major crops can be grown in river bed farming system}

The major crops which can be grown by farmers along the river beds are water melon (Citrullus lanatus T.), bottle gourd (Lagenaria siceraria), cucumber (Cucumis stivus L.), summer squash (Cucurbita pepo L.), bitter gourd (Momordica charantia L.), pumpkin (Cucurbita moschata D.), pointed gourd (Trichosanthes dioica R.) and sponge gourd (Luffa cylindrical R.). Few farmers also grew chillies, beans, tomato and other high value vegetables on the riverbeds. The choice of crop entirely depends on soil conditions and water availability.

\section{River-bed soils}

A well-drained soil of loamy type is preferred for cucurbits. Lighter soils which warm 
quickly in springs are usually utilized for early yields, and in heavier soils vine growth will be more and fruits late in maturity. In sandy river-beds alluvial substrate and subterranean moisture of river streams support the cucurbits. In fact, a long tap root system is adapted to the growth of cucurbits in riverbeds.

The soils should not crack in summer, and should not be water-logged in rainy season. It is also necessary that soils should be fertile and provided with adequate organic matter. All the cucurbits are sensitive to acid soils. Soil below $\mathrm{pH}$ of 5.5 no cucurbits can be successfully grown and most of the cucurbits prefer a soil $\mathrm{pH}$ between 6.0 and 7.0. Musk melon is slightly tolerant to soil acidity, while other cucurbits prefer intermediate or normal $\mathrm{pH}$. Similarly alkaline soils with heavy salt deposition are unsuitable for cucurbits and water melon is the only cucurbit which is slightly tolerant to salts.

\section{Soil temperature}

Soil temperature is also a determining factor for quick germination, early maturity and production. For proper growth and development the minimum temperature should not go below $10^{\circ} \mathrm{C}$ and maximum of $25^{\circ} \mathrm{C}$. The optimum range should be around $18-22^{\circ} \mathrm{C}$.

\section{Systems of planting}

Majority of farmers choose either the pit or the ditch system of planting. It also depends on personal preferences and availability of labour.

\section{Pit system of Planting}

Starting closest to the water's edge, crops are planted in rows oriented according to the prevailing wind direction. For the pit system, pits of $0.5 \mathrm{~m}$ diameter are dug $1 \mathrm{~m}$ deep and 1 to 3 meters apart depending on the crops, and planted with multiple seeds, the weakest of which are thinned out.

\section{Ditch system of planting}

To use the ditch system, a trench $1 \mathrm{~m}$ deep is dug along the row, with 1 to $2 \mathrm{~m}$ (cucumber, bitter gourd) or $3 \mathrm{~m}$ (watermelon, bottle gourd, pumpkin) space between rows. Seeds are planted/spaced $0.5 \mathrm{~m}$ (cucumber, bitter gourd) to $1 \mathrm{~m}$ (watermelon, bottle gourd, pumpkin) apart in the ditch.

\section{Seed rate, seed treatment and sowing/ transplanting time}

A seed rate varies according crops to be grown. Generally for cucumber $2-3 \mathrm{~kg}$, bitter gourd and bottle gourd 4-5 kg, sponge gourd and ridge gourd $3 \mathrm{~kg}$ in one hectare area. The sowing of seed is generally done for early crop in first and second week of November and some time by first week of December. Late sowing is done in first week of January. The seeds are sown at a distance of 45-60 cm in the trench at a depth of 3 to $4 \mathrm{~cm}$.

Two seeds are generally sown at one place. If the temperature is very low, pre sprouted seeds are sown for smooth germination. For this, seeds should be presoaked for 24 hours and latter on moist seed should be kept in gunny bag or covered with cotton cloth and kept for a week in warm place to get sprouted.

Sometime growers wrap moisten seeds in gunny bags are caster leaves near the fiber burn for quick germination and in this way sprouting start after 5-6 days. As soon as sprouts are visible outside the seed coat they are planted. Generally, 3-4 pre-germinated seeds/hills in pits are sown. But in Andhra Pradesh one week old seedling are planted in pits or trench. 


\section{Manures and fertilizers}

Earlier no practices of manures and fertilizers were used for diara land cultivation but now day's farmers started using fertilizer and since crop is taken only for one season, so organic manures and fertilizers are used. Welldecomposed FYM or compost, groundnut or caster cake is given in first application. River silt is generally used to enhance retentivity of moisture in the feeding zone. These organic manures provide some kind of warmth to the germinating seeds or growing transplants. After 25-30 days after sowing, depending on growth and weather conditions, top dressing of chemical fertilizers in two split doses is done, especially of nitrogenous fertilizers like urea or fertilizer mixtures. This top dressing is applied away from the plants in shallow trenches. Cakes like groundnut cake in Maharashtra and A.P. or castor cake in Gujarat are also applied.

When the vines grow, they are spread over the sand and before that trenches are leveled up and the stubbles of grass are spread over the sand on the interspaces between the rows of the plants. The protection is provided by thatch screen made of locally available materials like Paddy straw, Saccharum grass or sugarcane leaves. In the month of February, grass is spread over the sand as a mulch and bedding. This helps to protect the young and tender plants/fruits from heat of scorching sand during summer and also avoids drifting of vines during strong winds.

\section{Weed management}

In diara land areas major weeds are Polygonum sp., Euphorbia hirta, Eclipta prostrata, Sida sp. and Fimbristlylis dichotoma etc. These weeds can be eradicated manually by pulling, since soil is quite loosened due to excess sands. No weedicide should be used because it may mix with running water of river and may prove hazardous to human, animal and fishes.

\section{Thatch preparation}

In northwest India, when the winter goes down $1-2^{0} \mathrm{C}$ in Dec-Jan, young plants require protection in early stages against low temperature and frost. The protection is provided by thatch screen made of locally available material like paddy straw, Saccharam grass or sugarcane leaves. In the month of February, grass is spread over the sand as a mulch and bedding. This helps to protect the young and tender plants and fruits from scorching of heat sand during summer and also avoids drifting of vines during strong winds.

\section{Cropping pattern}

Bottle gourd, cucumber and sponge gourd in North India and ridge gourd in Rajasthan, MP and UP and pointed gourd in Bihar.

\section{Harvesting of fruits}

In cucurbits harvesting should be done when fruits are quite tender and edible. Kartoli, kakrol and pointed gourd start flowering after 50, 60 and 80 days of transplanting, respectively. Edible mature fruits should be harvested at 2-3 days interval, otherwise, quality deterioration start and fruits hardened due to seed maturity. Harvesting at regular interval can be done by the end of June to end of October.

\section{Yield, marketing and storage}

The yield from river-beds of different cucurbits is naturally variable depending upon the location and the number of crops constituting mixed cropping. The melon fruits come to the market in February-March, in Andhra Pradesh, slightly later in April in 
Maharashtra and Rajasthan, extending to June in West Uttar Pradesh and Haryana. Other cucurbits come earlier because they are picked in edible (vegetable) maturity stage, like bottle gourd in March. The pumpkins arrive late in the market, since it is of longer duration. In years of unseasonable rainfall or floods in the rivers, the crop gets damaged and resowing has to be done.

The mixed cropping has some advantages in that situation as it gives river-bed farmers continuous income from March to June and cushions the losses or failure of anyone crop. Generally the cucurbits fruits mature faster, immediately after fruit setting. Picking of fruits at the right edible maturity stage and regular intervals is dependent on the individual kind and varieties. In salad slicing cucumber, dark green skin color should not turn brownish yellow, or rusting and white spine color is a suitable indication for edible maturity. In small fruited type, pale green skin color is also indicative of edible maturity. In musk melon there are two groups of cultivars which behave distinctly. In one group, when fruit matures, slips out easily from the vine (Full slip stage) viz. Lucknow Safeda, Durgapura Madhu, Cantaloupes of the U.S.A etc.

The other group of melons e.g. Honey Dew and Casaba, the fruits are not separated. They have to be removed on the basis of external colors. In some Indian cultivars green stripes on the skin turns yellow giving indication of edible maturity. Most of the cucurbits in India are not stored except pumpkin and ash gourd. They generally have short storage life for a few weeks under $10^{\circ} \mathrm{C}$ with 60 to 70 percent relative humidity. All the cucurbits are not usually processed. In India, ash gourd is processed in sugar syrup and "petha" is the common native confectionery prepared from ash gourd in North India. There is a welldeveloped cucumber pickle industry in USA

\section{Constraints}

The farmers enraged in this business face several problems in taking up river-bed cultivation. The major constraints are:

\section{Non availability of quality seed}

River-bed culture of melons has been developed through the native ingenuity of the farmers.

They keep the seeds of the fruits which are found sweet in season, unmindful and unwary of the fact that most of these fruits are produced by cross pollination before selection of the fruit for seed extraction. That is the reason why the fruits coming from river-beds are of undependable quality, especially in sweetness and flesh color, of which urban consumers often complains.

Since each farmer keeps his own seed, there is no guarantee that a cultivar will remain pure in river-bed culture for more than one season. It has enabled the perpetuation of natural variability and there has been a continuous process of recombination and selection involuntarily promoted by the farmers. The major problem other than seed is availability of land. Sometime the river-bed remains for a longer period underwater.

Since the vegetable growers are not the owner of land availability of land is uncertain. Long term lease is desired.

In some rivers the course of the river changes creating problems.

New river bed areas are to be cultivated by growers.

Due to heavy leaching of the soils, fertility is very low. Growers require putting extra efforts for manures etc. 
In spite of high water table irrigation is also a problem. Small water lifting mechanism or bamboo tube wells may help the growers, if provided on subsidized basis.

River-bed cultivation practice does not fit in any of the crop rotation, and cucurbits are especially adopted for such type of cultivation. A large number of problems are faced by the growers, starting from the uncertainty of availability of land on long term basis, sometimes river-course shifting fertility status, leaching, irrigation etc. besides the availability of good quality of seed. In spite of all these problems a large number of growers are engaged in cultivating cucurbits in the river-bed areas, especially in summer growing large quantity of musk melon, water melon, cucumber etc.

This type of cultivation is best suited for small and marginal farmers, who can work themselves along with their families in the fields, producing a large number of cucurbits and other vegetables economically. The major share of benefit is usually taken by the business man and middle man who purchase the cucurbits vegetables in summer and sale it in market. Thus, the small and marginal farmers who raised a good crop on river-bed or practically on sand, is deprived of his major share of profits. By utilizing an underexploited resource and enhancing small holders' productive skills on marginal soils, riverbed farming increases marginal farmer's options for sustainably coping with the effects of environmental shocks like floods.

\section{References}

Chandy KT. River bed Cultivation of Vegetables. Agricultural and Environmental Education Booklet No. 410, Vegetable Production: VPS-4.

Panda BC. Monitoring of the diara lands of Eastern India with respect to vegetation, wasteland, soil erosion and Inundation through remote sensing techniques. Division of Agricultural Physics, Indian Agricultural Research Institute (IARI) New Delhi-110 012.

Patel HB, Saravaiya SN, Kumar S and Patel AI. 2016. Riverbed farming. Innovative Farming -An International Journal of Agriculture 1(3): 106-107.

SATNET Asia. 2014. Leasehold Riverbed Vegetable Farming.

Singh PK. 2012. Cucurbits cultivation under Diara land. Asian Journal of Agriculture and Rural Development 2(2): 248-252.

\section{How to cite this article:}

Reena Kumari, Ankita Sharma, Shikha Bhagta and Ramesh Kumar. 2018. River Bed Cultivation: A Kind of Vegetable Forcing for Remunerative Returns. Int.J.Curr.Microbiol.App.Sci. 7(04): 359-365. doi: https://doi.org/10.20546/ijcmas.2018.704.041 